\title{
Persistence of Imazapic and Imazapyr in Paddy Soil and Water
}

\author{
Bajrai F.S.M., Ismail B.S., Mardiana-Jansar K. and Omar R.
}

\begin{abstract}
Studies on the persistence of imazapic and imazapyr in a Malaysian soil, namely clay loam and in water, were conducted under greenhouse conditions. The experiment was carried out in clay loam soil of the Sungai Besar paddy plantation area, in Selangor, Malaysia. An analytical method based on an extraction procedure and followed by high-performance liquid chromatographic (HPLC) separation with multi variable detection was optimized and validated for the simultaneous determination of imazapyr and imazapic. Chromatographic separation was carried out with the C8 column. The estimated values of the half-life of imazapyr in water for 75, 150 and $300 \mathrm{~g}$ ai/ha following first order kinetics were 22.00, 23.34 and 22.29 days, respectively. Meanwhile for imazapic, the estimated half-life in water for 75,150 and $300 \mathrm{~g}$ ai/ha following first order kinetics were $23.11,23.74$ and 21.59 days, respectively. As for soil, the degradation rates of $26.26,29.75$ and 25.30 days were observed as the estimated half-life values for imazapyr and $38.51,34.15$ and 25.02 days for imazapic for the treatments of 75, 150 and $300 \mathrm{~g}$ ai/ha respectively. The rates of degradation of both active ingredients were slower in soil than in water. These results are informative to both farmers and researchers to enable them to keep track on the environmental effects of selected herbicides so that the probability of unwanted ecological effects can be minimized.
\end{abstract}

Keywords - Imazapic, imazapyr; half-life, persistence; water; soils

\section{INTRODUCTION}

The application of herbicides in the rice cultivation industry is one of the often used methods to control weeds. According to Toriyama [1], herbicides were applied before rice germination to ensure well weed-controlled on the early stages of the rice development because weeds compete and multiply easily in the rice ecosystem. Since weeds can be controlled at the initial stages of their growth, ploughing activities could be reduced and thus moisture and nutrient content in the soil maintained. In fact, herbicides are also capable of controlling weed-like plants that grow in cultivated areas [2]. Effective control of weedy rice and weeds in the early stages of their development prevent weed competition and crop damage in direct seeding crops and therefore increase the production of better quality rice [3-4].

In rice cultivation, weedy rice is one of the biggest challenge that could create negative effect. This statement was also supported by Tewari [5] where weedy rice which has higher bud compete with ordinary rice for nutrients, moisture, and sunlight. This affects the photosynthesis process of rice and thus causes a

Manuscript received November 15, 2016. The authors are grateful for the GUP-2014-087 grant, BASF Malaysia and Universiti Kebangsaan Malaysia for their financial support.

Bajrai F.S.M., Ismail B.S., Mardiana-Jansar K. and Omar R. are with the School of Environmental and Natural Resource Sciences, Faculty of Science \& Technology, Universiti Kebangsaan Malaysia, 43600 Bangi, Selangor, Malaysia reduction in the quantity and quality of rice. Chauhan [6] in his research reported that weedy rice can cause yield losses of $50-60 \%$ on moderate invasion (15-20 stems m-2) and $70-80 \%$ on high invasion (21-30 stems m-2). A study conducted by Moody [7] stated that the invasion of weedy rice in tropical Asian countries is increasing with the increase of direct seeding method; the method thet is most preferred by farmers.

To help reducing the problem of weedy rice in paddy plantation, Clearfield Production System was introduced in early 2000 [8]. According to Azmi et al. [9], Clearfield Production System (CPS) contains the seeds of rice varieties have a gene tolerant to imidazolinone herbicides (OnDuty ${ }^{\mathrm{TM}}$ ). Imidazolinone herbicide consist of imazapic and imazapyr as its active ingredients that can control weedy rice along with other various weeds effectively [9]. According to Senseman et al. [10], the active ingredient of imazapic is often used in the control of annual grassy weeds, grasses that persist during pre and post-germination periods as well as broadleaf weeds, while imazapyr is used to control various types of grasses, broadleaf weeds, woody weed species as well as riparian and aquatic weed species. A summary of the active ingredients' (imazapic \& imazapyr) characteristics and chemical properties are presented in Table 1.

\begin{tabular}{|c|c|c|}
\hline Parameter & Imazapic & Imazapyr \\
\hline PAC name & $\begin{array}{l}( \pm)-2-[4,5-d i h y d r o- \\
\text { 4-methyl-4-(1-met } \\
\text { hylethyl)-5-oxo-1H } \\
\text {-imidazol- } \\
\text { 2-yl]-5-methyl-3-p } \\
\text { yridinecarboxylate, } \\
\text { 2-(4-iso-propyl-4- } \\
\text { methyl-5-oxo-2-im } \\
\text { idazolin-2-yl)-5-m } \\
\text { ethylnicotinicacid }\end{array}$ & $\begin{array}{l}\text { 2-propanamine, } \\
\text { 2-(4,5-dihydro-4- } \\
\text { ethyl-4-(1-methyl } \\
\text { ethyl)-5-oxo-1H- } \\
\text { imidazol-2-yl)-3- } \\
\text { pyridinecarboxyl } \\
\text { ate, } \\
\text { 2-(4-isopropyl-4- } \\
\text { methyl-5-oxo-2-i } \\
\text { midazolin-2-yl)- } \\
\text { nicotinic acid }\end{array}$ \\
\hline Chemical formula & $\begin{array}{l}\text { Acid: } \\
\text { C14,H17,N3,O3 } \\
\text { Salt: } \\
\text { C14,H20,N4,O3 }\end{array}$ & $\begin{array}{l}\text { Acid: } \\
\text { C13,H15,N3,O3 } \\
\text { Salt : } \\
\text { C16,H24,N4,O3 }\end{array}$ \\
\hline $\mathrm{p} K \mathrm{a}$ & $2.0,3.9,11.1$ & $1.9,3.6,11$ \\
\hline $\begin{array}{l}\text { Solubility inwater, } \\
\text { mg L-1 }\end{array}$ & 2200 & 11272 \\
\hline $\mathrm{K}_{\mathrm{OC}}$ & 137 & $100 \mathrm{~mL} \mathrm{~g} \mathrm{-1}$ \\
\hline Kow & 2.47 & 1.3 \\
\hline Soil half-life & $120 \mathrm{~d}$ & $90 \mathrm{~d}$ \\
\hline
\end{tabular}

Data quoted from Senseman at al. [10] and Tu et al. [11]

Persistence refers to the soil's ability to hold any kind of pesticides and not allowing them to be transported [12]. In this case, a more stabil herbicides compounds require a longer time to be broken down [13]. The application of imazapic and imazapyr for controlling weedy rice in the Malaysian 
agricultural system may somehow create an environmental effect in both the water and soil media if they have a long persistency. Therefore, it is important to understand the actual behaviour of these compounds in order to determine their potential risk to the environment. The present study was conducted to investigate the contamination levels of herbicide residues in two environmental samples namely water and soil. The water and soil samples were periodically collected and tested to detect the levels of herbicide residues.

\section{MATERIALS \& METHODS}

The herbicide that is made up of imazapic and imazapyr as active ingredients was used in the study. Both compounds belong to the imidazolinone chemical group formulated in $150 \mathrm{~g}$ ai ha-1 solution. $100 \mathrm{~kg}$ of soil was collected from a paddy plantation area in Sungai Besar, Kuala Selangor (GPS coordinates of $3^{\circ} 42^{\prime} 01.9^{\prime \prime} \mathrm{N} 101^{\circ} 00^{\prime} 23.2^{\prime \prime E}$ ). The soil samples collected from the sampling area were filled into $64 \mathrm{~cm} 3$ plastic pots. The factorial arrangement was incorporated into the bock design with four replications. The rates of herbicides spraying used were the recommended dosage (150 g ai ha-1), half the recommended dosage (75 $\mathrm{g}$ ai ha-1), double the recommended dosage (300 g ai ha-1) and the control (with no herbicide treatment). The herbicide was applied to the prepared pots on May 2015.

\section{A. Water sampling}

Water samples (three replications) were collected from the surface area at 0 (day of spraying), 1, 3, 7, 21, 30, 60 and 120 days after treatment.

\section{B. Soil sampling}

Soil samples (three replications) were collected from the top most soil layer (depth $0 \mathrm{~cm}$ to $10 \mathrm{~cm}$ ) at 0 (day of spraying), 1, 3, 7, 21, 30, 60 and 120 days after treatment. The soil characteristics are summarized in Table 2.

TABLE 2: PHYSICO - CHEMICAL PROPERTIES OF THE CLAY LOAM SOIL

\begin{tabular}{ll}
\hline Parameter & Clay Loam \\
\hline $\mathrm{pH}$ & 4.29 \\
$\%$ Organic matter & 9.05 \\
$\mathrm{CEC}(\mathrm{meq} / 100 \mathrm{~g})$ & 5.4618 \\
Sand $(\%)$ & 32 \\
Silt $(\%)$ & 37 \\
Clay $(\%)$ & 32 \\
Exchangeable $\mathrm{Al}(\mathrm{meq} / 100 \mathrm{~g})$ & 0.6 \\
\hline \hline
\end{tabular}

*Data reported are mean values estimated from 3 replicates

\section{Recovery study}

In the recovery study each soil and water sample (5 g) was treated with the combinations of both imazapyr and imazapic. For each pesticide, the soil sample was spiked at one concentration i.e. $1 \mathrm{mg} \mathrm{kg}$ - 1 . The pesticide was then extracted from the soil for determination of the imazapic and imazapyr residue.

\section{Determination of imazapyr and imazapic in the soil and water}

Analyses of the samples of water and soil were carried out using the method proposed by Moser [14] with slight modifications. Soil and water samples were placed separately in $50 \mathrm{~mL}$ centrifuge tubes. Extraction was the carried out by initially adding $10 \mathrm{~mL}$ of $10 \mu \mathrm{M}$ ammonium acetate. The mixture was then shaken in a vortex mixer for 30 seconds, then centrifuged for 5 minutes at a speed of $4000 \mathrm{rpm}$. Then $1.0 \mathrm{~mL}$ of the supernatant from each extraction was directly injected into $2 \mathrm{~mL}$ vials via $0.2 \mathrm{~m}$ nylon filter. Analyses were carried out using a HPLC (Agilent Technology Model 1220 LC equipped with UV detector). The details of conditions used in the study are summarized as in Table 3.

\begin{tabular}{|c|c|}
\hline Column & Agilent ZORBAX Eclipse Plus C8 \\
\hline Length & $2.1 \times 150 \mathrm{~mm}$ \\
\hline Diameter of the column & 5 micron \\
\hline Column Temperature & $25 \pm 3^{\circ} \mathrm{C}$ \\
\hline Flow rate & $0.3 \mathrm{ml} / \mathrm{min}$ \\
\hline Wavelength & $300 \mathrm{~nm}$ \\
\hline Injection type & $5 \mu \mathrm{L}$ \\
\hline Mobile Phase & A : $0.1 \%$ Formic acid, B : Acetonitrile \\
\hline
\end{tabular}

Data quoted from Senseman at al. [10] and Tu et al. [11]

\section{RESULTS AND DISCUSSION}

The characteristics of the studied soil type, namely clay loam soil are presented in Table 2. The preliminary results of the recovery of imazapic and imazapyr in water and soil are shown in Table 4. The percentage recovery of imazapic and imazapyr obtained at $1 \mathrm{ppm}$ in the clay loam soil was $97.44 \%$ and $97.06 \%$, respectively, while in water, the percentage recovery was $100 \%$ and $88.24 \%$, respectively.

TABLE 4. RECOVERY STUDY OF IMAZAPIC AND IMAZAPYR IN SOIL AND WATER

\begin{tabular}{lll}
\hline \hline Concentration $(\mathbf{1} \mathbf{~ p p m})$ & Imazapic & Imazapyr \\
\hline Soil & $97.44 \pm 4.44$ & $97.06 \pm 2.94$ \\
Water & $100.00 \pm 6.66$ & $88.24 \pm 7.64$ \\
\hline \hline \multicolumn{2}{c}{ *Data reported are mean values estimated from 3 replicates }
\end{tabular}

Studies to quantify the degradation rates for imazapic and imazapyr were conducted using the high-performance liquid chromatograph (HPLC). The first-order rate constant "c" was determined from the slope of the linear plot of the natural logarithm of the remaining herbicide concentration $[\ln (\mathrm{C} / \mathrm{C} 0)]$ at various sampling intervals, in relation to time. The dissipation time (DT50), i.e. the time taken for the concentration of the pesticide to be reduced to $50 \%$ of its initial concentration, was calculated using the equation DT50 $=\ln (2) / k$, where $\mathrm{k}$ is the absolute value of the slope and the first-order rate constant for the herbicide [15]. Figs. 1 and 2 indicating the pattern of degradation for both imazapic and imazapyr compounds at different concentrations in soil and water medium. 


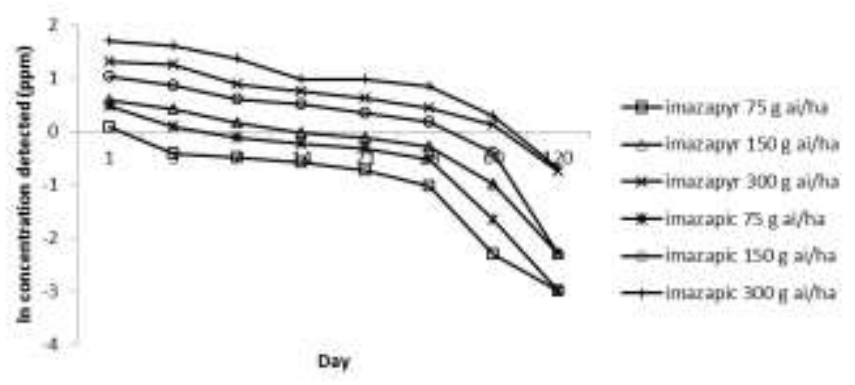

Fig.1. Degradation of imazapic and imazapyr at different concentrations in water samples.

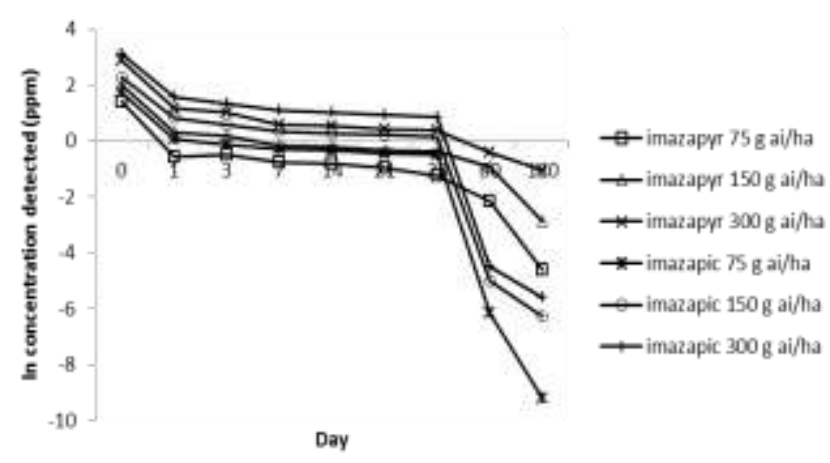

Fig. 2. Degradation of imazapic and imazapyr at different concentrations in soil samples.

The estimated half-life values of imazapyr in water for 75, 150 and $300 \mathrm{~g}$ ai/ha following first order kinetics were 22.00 and 23.34 and 22.29 days, respectively. Meanwhile, for imazapic, the estimated half-life values in water for 75, 150 and $300 \mathrm{~g}$ ai/ha following first order kinetics were 23.11, 23.74 and 21.59 days, respectively.

TABle 5. Correlation CoEfFicients (R2), Degradation Rate COEFFICIENTS (K), AND HALF-LIFE (DAYS) OF IMAZAPIC AND IMAZAPYR AT DIFFERENT CONCENTRATIONS IN WATER SAMPLES

\begin{tabular}{ccccccc}
\hline Dose & \multicolumn{3}{c}{ Imazapic } & \multicolumn{3}{c}{ Imazapyr } \\
\cline { 2 - 7 } & $\mathrm{R}^{2}$ & $\mathrm{k}$ & $\mathrm{t}_{1 / 2}$ & $\mathrm{R}^{2}$ & $\mathrm{k}$ & $\mathrm{t}_{1 / 2}$ \\
\hline $\begin{array}{c}\text { At half the } \\
\text { recommended } \\
\text { rate }\end{array}$ & 0.83 & 0.030 & 23.11 & 0.83 & 0.032 & 22.00 \\
$\begin{array}{c}75 \mathrm{~g} \text { ai/ha) } \\
\text { At the } \\
\text { recommended } \\
\text { rate }\end{array}$ & 0.93 & 0.029 & 23.74 & 0.92 & 0.030 & 23.34 \\
$\begin{array}{c}(150 \mathrm{~g} \text { ai/ha) } \\
\text { At double the } \\
\text { recommended } \\
\text { rate }\end{array}$ & 0.90 & 0032 & 21.59 & 0.92 & 0.031 & 22.29 \\
$(300 \mathrm{~g}$ ai/ha) & & & & & & \\
\hline
\end{tabular}

With references to the soil degradation rates, 26.26, 29.75 and 25.30 days were observed as the estimated half-life values for imazapyr at 75, 150 and $300 \mathrm{~g}$ ai/ha, respectively. On the other hand, for imazapic, the estimated half-lives were 38.51, 34.15 and 25.02 days for 75, 150 and $300 \mathrm{~g}$ ai/ha, respectively. Based on the above results, the rates of degradation for both active ingredients were slower in soil than in water.
TABLE 6. CORRELATION COEFFICIENTS (R2), DEgRADATION RATE COEFFICIENTS (K), AND HALF-LIFE (DAYS) OF IMAZAPIC AND IMAZAPYR AT DIFFERENT CONCENTRATIONS IN THE SOIL SAMPLES

\begin{tabular}{ccccccc}
\hline Dose & \multicolumn{3}{c}{ Imazapic } & \multicolumn{3}{c}{ Imazapyr } \\
\cline { 2 - 7 } & $\mathrm{R}^{2}$ & $\mathrm{k}$ & $\mathrm{t}_{1 / 2}$ & $\mathrm{R}^{2}$ & $\mathrm{k}$ & $\mathrm{t}_{1 / 2}$ \\
\hline $\begin{array}{c}\text { At half the } \\
\text { recommended } \\
\text { rate }\end{array}$ & 0.81 & 0.018 & 38.51 & 0.94 & 0.025 & 26.26 \\
$\begin{array}{c}\text { (75 g ai/ha) } \\
\text { At the } \\
\text { recommended } \\
\text { rate }\end{array}$ & 0.74 & 0.020 & 34.15 & 0.80 & 0.023 & 29.75 \\
$\begin{array}{c}(150 \mathrm{~g} \text { ai/ha) } \\
\text { At double the } \\
\text { recommended } \\
\text { rate } \\
(300 \mathrm{~g} \text { ai/ha) }\end{array}$ & 0.82 & 0.021 & 25.02 & 0.78 & 0.027 & 25.30 \\
\hline
\end{tabular}

The findings of the present study are consistent with those of a study conducted by Douglas et al (2013) where it was reported that imazapyr breaks down very rapidly via photolysis in water. Imazapic on the other hand is degraded primarily by soil microbial metabolism. However, the degradation of imazapic by sunlight is believed to be minimal when it is applied to terrestrial plants or soil, but it is rapidly degraded by sunlight in aqueous solutions [16]. Imazapyr residues can be relatively persistent in soils (reported soil half-life $(\mathrm{t} 50)=25-142$ days) depending on soil texture, organic matter content, $\mathrm{pH}$ levels and environmental factors that promote microbial degradation [10-17].

Many factors affect the persistence of pesticides in the soil environment. Environmental factors, such as temperature, soil moisture, microbial activity, pesticide properties and their characteristics, in particular solubility, have great influence on the persistence and mobility of pesticides [18].

One of the precautions that must be taken into consideration is that the present study was undertaken in the green house, using pots. Therefore, there is the probability that slower degradation in the solution could be due to the fact that no water flowed out of the pots. As for soil degradation, microbial activity usually is the highest in warm, moist, well-aerated soils of neutral $\mathrm{pH}$. The constantly warm temperature in Malaysia and the relatively high organic matter content in the soils could enhance the degradation rate of pesticides in the soil. This finding could be supported by a study conducted by Castillo et al. [19] reported that higher temperatures and sunlight in tropical countries might increase pesticides' degradation rates.

\section{CONCLUSION}

The values of the half-life of imazapyr under the conditions of the present study ranged from 22 to 30 days while those of imazapic ranged from 21 to 39 days indicating longer persistence of the latter herbicide in the environment. This study indicated that the potential impact of these herbicides is minimal due to their lower persistency in the paddy environment.

\section{ACKNOWLEDGMENT}

The authors are grateful for the GUP-2014-087 grant, BASF Malaysia and Universiti Kebangsaan Malaysia for their financial support. 


\section{REFERENCES}

[1] K. Toriyama, K. L. Heong and B. Hardy. B. Rice Is Life: Scientific Perspectives for the 21st Century. Philippines: International Rice Research Institute, 2005.

[2] R. Jayakumar and R. Jaganathan, Weed Science Principle. New Delhi: Kalyani Publishers, 2007.

[3] S. K. D. D. Kwesi Ampong-Nyarko. A Handbook for Weed Control in Rice. Manila. Philippines: International Rice Research Institute, 1991.

[4] Singh, Y., G. B. P. U. O. Agriculture, I. R. R. Technology \& Institute.. Direct Seeding of Rice and Weed Management in the Irrigated Rice-Wheat Cropping System of the Indo-Gangetic Plains. Directorate of Experiment Station, G.B. Pant University of Agriculture and Technology, 2008.

[5] A. N. Tewari, 2008. "Weedy Rice and Its Management," in Direct Seeding of Rice and Weed Management in the Irrigated Rice-Wheat Cropping System of the Indo-Gangetic Plains, Y. Singh, V. P. Singh, B. Chauhan et al., Ed. Los Baños, Philippines: International Rice Research Institute, p. 206.

[6] B. S. Chauhan. Management Strategies for Weedy Rice in Asia. Los Baños (Philippines): Institute Rice Research International, 2013.

[7] K. Moody. Weedy Forms of Rice in Southeast Asia. MARDI workshop on Padi Angin, 1994, p. 5.

[8] J. E. Rosas, V. Bonnecarrère and F. Pérez de Vida. One-step, codominant detection of imidazolinone resistance mutations in weedy rice (Oryza sativa L.). Electron. J. Biotechnol., vol. 17, no. 2, 95-101, 2014. https://doi.org/10.1016/j.ejbt.2014.02.003

[9] Azmi, S. Azlan, S.E. Chew and T.V. George. Control of weedy rice in direct-seeded rice using the Clearfield Production System in Malaysia. Pak. J. Weed Sci. Res., vol. 18, pp. 49-53, 2012.

[10] S. A. Senseman, K. Armbrust and W. S. S. America. Herbicide Handbook 2007. Lawrence: Weed Science Society of America, 2007.

[11] M. Tu, C. Hurd, and J. Randall. Weed Control Methods Handbook: Tools and Techniques for Use in Natural Areas. The Nature Conservancy, Wildland Invasive Species Team, 2001, 7 March 2016; http://tncweeds.ucdavis.edu/handbook.html)

[12] K. M. A. Jaradat "Adsorption and desorption characteristics of endosulfan pesticide in three soils in Palestine," Thesis Science In Chemistry, An-Najah National University.

[13] R. Zanella, M. B. Adaime, S. C. Peixoto, C. D. A. Friggi, O. D. Prestes, s. L. Machado, E. Marchesan, L. A. Avila and E. G. Primel. Herbicides persistence in rice paddy water in Southern Brazil. Mohammed Naguib Abd El-Ghany Hasaneen vol. 183, 2011. https://doi.org/10.5772/32727

[14] S. C. Moser. A fast and easy method for Imidazolinone residue analysis. Unpublished manuscript, Oklahoma Department of Agriculture, Oklahoma City, OK. 2010.

[15] G. B. Reimche, S. L. D. O. Machado, R. Zanella, M. C. D. Vicari, F. Piccinini, J. I. Golombieski, and L. Reck. Zooplankton community responses to the mixture of imazethapyr with imazapic and bispyribac-sodium herbicides under rice paddy water conditions. Ciência Rural, vol. 44(8), pp. 1392-1397, 2014. https://doi.org/10.1590/0103-8478cr6151

[16] American Cyanamid Company. Plateau herbicide, for weed control, native grass establishment and turf growth suppression on roadsides and other noncrop areas. PE-47015. Parsippany, NJ, 2000.

[17] S. J. Nissen, A. A. Sher and A. Norton. Tamarisk: Best Management Practices in Colorado Watersheds. Fort Collins, CO: Colorado State University, 2010

[18] P. Liu, Y. Liu, Q. Liu, and J. Liu. Photodegradation mechanism of deltamethrin and fenvalerate. J. Environ. Sci., vol. 22, no. 7, pp. 1123-1128, 2010. https://doi.org/10.1016/S1001-0742(09)60227-8

[19] L. E. Castillo, E. De la Cruz, and C. Ruepert. Ecotoxicology and pesticides in tropical aquatic ecosystems of Central America. Environ. Toxicol. Chem., vol. 16, no.1, pp. 41-51, 1997. https://doi.org/10.1002/etc.5620160104

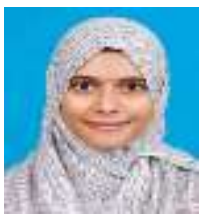

Fatimah S.M. Bajrai was born in Johor, Malaysia on July 1989. In 2013, she received a bachelor's degree in Science with Distinction majoring in environmental science from Universiti Kebangsaan Malaysia. She currently pursuing her Ph.D in the same university.

She worked as a research assitant before pursuing her $\mathrm{PhD}$ for 8 months assisting undergraduates students in the

Pesticide Lab.

Her research interests focus on the detection of the herbicides compound in the paddy field environment and modeling its environmental effects towards the environment. Miss Bajrai's recent publication including AIP Conference Proceedings (2015).

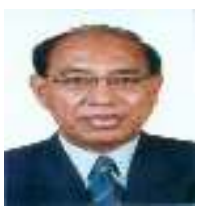

Ismail B. Sahid was born on 5 October 1951 in Penang, Malaysia. He received his secondary education from SMK Panglima Bukit Gantang, Perak, Malaysia. After that he was enrolled at Kolej Islam Malaya, Petaling Jaya, Selangor, Malaysia (1969-1970). He received a BSc in Biology from Universiti Kebangsaan Malaysia (UKM) in 1975 and PhD (Botany) in 1978 from University of Sheffield, United Kingdom. Then, he joined UKM as a lecturer and appointed as Assoc. Professor in 1984. In 1993, he was appointed as a Professor. His researches of specialization are; Weed Biology/Management, Allelopathy and Environmental Toxicology.

He was awarded research grants from the Ministry of Science, Technology and Innovation, Malaysia (MOSTI) to study the impact of pesticide application in Malaysian agroecosystem. He also received a research grant from MONSANTO (2000-2006) to study the resistance of Eleusine indica toward glyphosate (Roundup®) and from the International Rice Research Institute (IRRI) in 2006-2008 to study the level of pesticide contamination in the MADA rice fields in Kedah, Malaysia. Recently, he received research grant from MOSTI. The study is to predict the pollution of pesticide using SWAT model. To date, he has written more than 300 articles in international journals not included a number of papers presented during the national and international conferences. He has supervised $40 \mathrm{PhD}$ and $60 \mathrm{MSc}$ students.

Prof. Ismail has received few awards such the most prolific author from UKM in 2003. The author also had received award on the best articles from Malaysian Palm Oil Board for two consecutive year 2003 and 2004 for discovering new and effective method for the detection of pesticide compounds in palm oil.

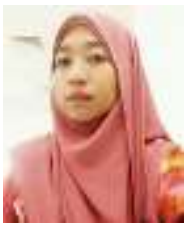

Mardiana Jansar was born in Melaka, Malaysia on 8th February 1982. She launched her career as a lecturer after graduating from Universiti Kebangsaan Malaysia (Master in Environmental Management) in 2006 and Universiti Sains Malaysia (Bachelor of Environmental Technology) in 2004.

She worked as a teacher in primary and secondary school after finishing her bachelor degree. With the passionate in teaching and research on environment she is now working with Universiti Kebangsaan Malaysia as a LECTURER. She has already published some of the findings of her research on water quality and pesticides contamination in few journals. Her main research topics and interest are about environmental pollution and management.

Ms. Mardiana-Jansar is a member of Environmental Management Society of Malaysia. Her recent publication is on residue determination and monitoring of the levels of metsulfuron methyl in selected rivers at Tasik Chini, Pahang, Malaysia (2016) and residue determination and levels of glyphosate in surface waters, sediments and soils associated with oil palm plantation in Tasik Chini, Pahang, Malaysia (2014).

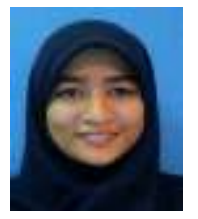

Rahimah was born on July 31, 1993, near Jeli, Kelantan, Malaysia, finished her study in bachelor's degree in Environmental Science at Universiti Kebangsaan Malaysia. She furthered to a master's Degree in Environmental Assessment and Monitoring from the same university on 2016.

Currently Rahimah Omar works as a researcher in Forest Research Institute of Malaysia and still developing her career path. Her interest is on water quality and pesticides analysis. 